\title{
Analysis of the Prevention of Terrorism in Indonesia
}

\author{
Ferroka Putra Wathan ${ }^{1}$, Megawati Barthos ${ }^{2}$ \\ Student Program Doctor of Law Borobudur University, J1. Pemuda, RT.1/RW.3, \\ Rawamangun, Kec. Pulo Gadung, DKI Jakarta 13220, Indonesia ${ }^{1,2}$ \\ \{ferrokaunbor@gmail.com¹,megawati_barthos@borobudur.ac.id²\}
}

\begin{abstract}
Terrorism is a crime against civilization and the most serious threat to the sovereignty of any country. Terrorism crimes are committed in an anarchic way that sacrifices innocent people. These crimes are committed in an organized and systematic manner by involving interstate networks. This paper uses a normative legal approach by reviewing regulations related to counter-terrorism in Indonesia. The Bali bombing case forced the Indonesian Government to issue a Replacement Government Regulation Law No. 1 of 2002 on the Eradication of Terrorism and Perpu Crime No. 2 of 2002 concerning the Implementation of Government Regulation No. 1 of 2002, which the House of Representatives later ratified with Law No. 15 of 2003 and Law No. 16 of 2003.
\end{abstract}

Keywords: Deradicalization; Crime of Terrorism; Prevention

\section{Introduction}

Terrorism is a crime that cannot be classified as an ordinary crime, academically terrorism is categorized as Extra Ordinary Crime and also categorized as a crime against humanity. Given this category, the eradication is certainly not able to use the usual means as to deal with the crime of theft, murder or persecution.

Terrorism in the world is not new, but it has become actual especially since the events of the World Trade Center (WTC) in New York and the Pentagon building in Washington, United States on September 11, 2001, known as the Black September or U.S. Attack that has inflicted a great variety of moral and material losses, not only for those who are victims, but also for the entire international community. As a result of the attack, business sectors such as the aviation industry, travel agencies, hospitality, tourism and the like experienced a drastic decline. U.S. Intelligence immediately conducted an investigation shortly after the September 11, 2001 attacks to find a motive and who should be responsible for the attacks. However, the tragedy of September 11, 2001 has given rise to a new paradigm of acts of international terrorism, especially with the United States (U.S.) establishing the Al-Qaeda group under Osama Bin Laden as the brains behind the attacks and becoming a prime target of the doctrine of global war on terrorism promoted by Former President George W. Bush as U.S. security policy.

Terrorism, not only threatens developed countries such as the United States, United Kingdom and Australia even occur in developing countries such as Indonesia. Terrorism cases in Indonesia came to light after the bali bombings on October 12, 2002, at Sari's Club and Paddy's Club in Kuta Bali which recorded, at least, 202 people killed and 300 injured, the 
tragedy of the jw marriot hotel bombing and Ritz-Carlton, Friday, July 17, 2009, which killed 9 people and struck dozens of others, it confirms how terror never stops threatening. A little negligent or careless in anticipating, terrorism will come with disasters and massive losses.

Of course, this series of bombing tragedies is a devastating blow to the Indonesian nation. Terrorism has always been synonymous with terror, violence, extremism and intimidation so it often has negative consequences for many people and can bring down many victims. Some terrorists in Indonesia consider themselves mujahid fi sabilillah. But Islam does not teach that and neither does it teach violence in spreading the teachings of Islam and carrying out the deeds of ma'ruf nahi munkar. In addition, Law No. 15 of 2003 concerning the Establishment of PERPU No. 1 of 2002 on the Eradication of Terrorism Crimes into Law on April 4, 2003,2 has always been a debate among the public because it is considered to restore military power and threaten the freedom that has been enjoyed by the people of Indonesia. This regulation is feared to take away the newly built democracy and try to be enforced in this beloved Indonesian earth. The doubt is considered reasonable because the Law is multiinterpretative and gives too much authority to the State which leads to excesses of human rights violations.

\section{Methods}

Research methods as an effective way of finding scientific truths are the author's concerning aspects of methods that include thinking to find a purpose. In this type of research, it is development research with a descriptive approach. Furthermore, the method of procedure that the author uses is normative legal research that is legal research conducted by researching library materials or secondary data. The legal materials are organised systematically, reviewed and then drawn a conclusion concerning the problem being examined.

In a study must be disclosed the type of data used is a type of secondary data where data obtained from sources whose data properties have been documented by other parties. Data collection for normative law research, writing use with literature study method. In this case, the author must be observant and precise to find the data in the legislation and in the literature that has a relationship with the problem that the author examines. Researchers conduct data processing in a qualitative way that is a method of data analysis that does not display numbers as a result of research but is presented in the form of discussion with a description of sentences and presented in writing.

\section{Discussion}

\subsection{Definition of Terrorism}

Basically the term terrorism is a concept that has a very sensitive connotation because terrorism causes the killing and abuse of innocent people. The words "terrorist" (perpetrator) and terrorism (action) come from the Latin word "terrere" which people make more shaky or electrifying. The word terror is also common in horror. In Arabic, terrorism is known as $\mathrm{Al}$ Irhab. From this, it can be understood that the word Al-Irhab (terror) means (to cause) fear. Irhabi (terrorist) means to do something that causes panic, fear, unnerving safe people, causes shock in their lives and work, and stops their activities, and causes disturbances in security, life and interaction. 
According to the 1937 United Nations Convention, terrorism is any form of crime directed directly at the State to create a record of terror against certain people or groups of people or society at large. Whittaker cited several notions of terrorism, among others, according to Walter Reich who said that terrorism is a strategy of violence designed to improve desired outcomes, by instilling fear among the general public. Walter Reich says that terrorism is a violent strategy designed to improve desired outcomes, by instilling fear among the general public. According to Abdullah Mahmud Hendropriyono, terrorism is a way or technique of intimidation with systematic targets, for the sake of a particular political interest.

Article 6 of Law No. 15 of 2003 states that any person who uses violence or threats of violence poses an atmosphere of terror or fear of people in a widespread way or inflicts mass casualties, by depriving them of liberty or loss of life and property of others, or resulting in damage or destruction to strategic vital objects or the environment or public facilities or international facilities, convicted of terrorism with the death penalty or life imprisonment or imprisonment for a maximum of 4 (four) years and a maximum of 20 (twenty) years. So in conclusion from some of the above definitions, terrorism is a way to achieve a certain goal by using violence or threats of violence carried out to create fear and drop as many victims as possible irregularly.

\subsection{History of the Development of Terrorism in Indonesia}

Terrorism is a disturbing phenomenon. Acts of terrorism often involve several countries. The real international sponsors are big countries. It should be understood that terrorism has now gone global and does not look at international borders. Terrorism in the world is not new, but it has become actual especially since the world trade center (WTC) event in New York, United States on September 11, 2001, known as "September Gray". The attacks were carried out by air, not using warplanes, but rather using commercial aircraft belonging to American companies themselves, so as not to be caught by United States radar. Three commercial aircraft belonging to the United States were hijacked, two of which were crashed into the twin towers of the Twin Towers World Trade Center and the Pentagon building. The incident, which killed at least 3,000 terrorized men, women and children, was killed, burned, killed and buried in tons of rubble in a planned mass murder. In the aftermath of the terrorist attack, according to the Twin Towers Orphan Fund, an estimated 1,500 children lost their parents. At the Pentagon in Washington, 189 people were killed, including the plane's passengers, and 45 died in the fourth plane that crashed in rural Pennsylvania. The terrorists thought that the attack on the WTC was an attack on the "American Symbol". However, the building they attacked is nothing but an international institution that symbolizes the prosperity of the world economy. There are representatives from various countries, namely there are 430 companies from 28 countries. So, actually, they're not only attacking the United States but the world. The United States suspects Osama bin Laden as the prime suspect in the attack.

The events of September 11, 2001 are events that have captured the attention of the world. These events have changed the landscape of the global order. Axial orism September 11, 2001 has hit the heart of global captalism, WTC. The concept of terrorism that was not so well known began to be studied and discussed by the people of the world. Whereas the terrorism movement already existed and several times occurred before the wtc building attack in the United States.

As part of the social phenomenon, terrorism is clearly evolving along with the development of human civilization. With the dissolution of the Soviet Union and neoliberal domination, the terrorism movement was further colored by religious ideological issues in 
which the WTC attack was a sign of magnitude. Indonesia did not escape the terrorist attacks with the Bali 1 bombings on October 12, 2002 and the Bali 2 bombings on October 1, 2005 which are considered the worst terrorism events in Indonesia's history. If we look at the various statements of terrorist perpetrators, Imam Samudra, for example, then deology and religious reasons seem to be the most powerful why someone becomes a terrorist. Until now religion has often been used as a base for the legitimacy of resistance through terror.

Terrorism in Indonesia is carried out by the Jemaah Islamiyah terror group which is directly linked to al-Qaeda. Jemaah Islamiyah adheres to salafy jihadi understanding, this became the basis of his movement in the span of time between 2000 to 2005. During this period the Jemaah Islamiyah group was in the spotlight because the perpetrators of these acts of terrorism, such as Hambali, Imam Samudra, Ali Imran, Ali Ghufran, Amrozi, Dr. Azahari Husein and Noordin M. Top were members of jemaah Islamiyah. These acts of terrorism are carried out not only to terrorize the enemy, but also for a broader purpose, namely to open the door of jihad as an obligation in the way of Allah against the infidels.

In its development, the bombings that occurred in Indonesia, which were linked to the activities of Jemaah Islamiyah from the group of Dr. Azahari and Noordin M. Top, were considered to have come out of jemaah Islamiyah members, because ideologically it had deviated from the organization's policy line. They are considered to have carried out terror activities that deviated from the policies of organizations that put forward da'wah as an effort to achieve the goal. The blasphemy of terror acts in Indonesia against the group of Dr. Azahari and Noordin M. Top is more apparent as an effort to simplify the problem.

Acts of terrorism in Indonesia, had a rapidly increasing frequency after the collapse of the new order. This can be seen from the bombings in a number of major cities, such as Jakarta, Medan, Surabaya, Makassar and other cities. Various bombings claimed lives and damaged existing facilities and infrastructure. Some of the terrorist acts that occurred significantly in Indonesia include:

a. On August 1, 2000, a bomb exploded at the Philippine Embassy. A bomb explodes from a car parked in front of the Philippine Ambassador's house in Menteng, Central Jakarta. Two people were killed and 21 others injured, including Philippine Ambassador Leonides T Caday.

b. Christmas Eve bomb, December 24, 2000. A series of Christmas Eve bomb blasts in several Indonesian cities claimed the lives of 16 people and injured 96 others and left 37 cars damaged.

c. On July 22, 2001, a bomb exploded at Santa Anna Church and HKBP, in Kalimalang Area, East Jakarta, 5 people were killed.

d. Bali bombings, October 12, 2002. Three explosions rocked Bali. A total of 202 victims, the majority of whom were Australian citizens, were killed and 300 others injured. At the same time, in Manado, North Sulawesi, an assembly bomb also exploded at the Philippine General's office, but there were no fatalities.

e. McDonald's restaurant bomb, Makassar, December 5, 2002. An assembled bomb wrapped in a steel plate container exploded at a McDonald's Makassar restaurant, killing three people and injuries.

f. Police Headquarters Complex Bomb, Jakarta, February 3, 2003, An assembled bomb exploded in the lobby of Wisma Bhayangkari, Jakarta Police Headquarters.

g. Soekarno-Hatta Airport Bombing, Jakarta, April 27, 2003. The bomb exploded in a public area at terminal $2 \mathrm{~F}$, Soekarno-Hatta International Airport, Cengkareng, Jakarta. Two people were seriously injured and eight others suffered moderate and minor injuries. 
h. JW Marriott bombing, August 5, 2003. The bomb destroyed part of the JW Marriott Hotel. A total of 11 people died, and 152 others were injured.

i. Australian Embassy bomb, September 9, 2004. A large explosion occurred in front of the Australian Embassy. Five people were killed and hundreds more injured. The explosion also caused damage to several surrounding buildings such as Plaza 89 Tower, Grasia Tower, and BNI Building.

j. $\quad$ Bomb blast at Immanuel Church, Palu, Central Sulawesi on December 12, 2004.

k. Two bombs exploded in Ambon on March 21, 2005. Also, the Tentena bombing, May 28, 2005, left 22 people dead.

1. Bali bombings, October 1, 2005. The bomb went off again in Bali. At least 22 people were killed and 102 others injured in the blasts at RAJA's Bar \& Restaurant, Kuta Square, Kuta Beach area and nyoman café jimbaran.

m. Palu Market Bomb, December 31, 2005. A bomb exploded at a market in Palu, Central Sulawesi that killed 8 people and injured at least 45 .

n. Jakarta bombing, July 17, 2009. Two devastating explosions occurred at jw marriott hotel and Ritz-Carlton, Jakarta. The explosion occurred almost simultaneously, around 7:50 a.m.

o. Shooting of civilians in Aceh January 2010, CIMB Niaga bank robbery September 2010.

p. Cirebon bombing, April 15, 2011. A suicide bomb blast at Cirebon's Mapolresta Mosque during Friday Prayers that killed the perpetrator and injured 25 others.

q. Gading Serpong Bomb, April 22, 2011. The bomb plot that targeted Christ Cathedral Church Serpong, South Tangerang, Banten and was placed in the gas pipeline, but was successfully foiled by the Indonesian Police.

r. Solo bomb, September 25, 2011. A suicide bomb blast at GBIS Kepunton, Solo, Central Java after services and congregations exit the church. One suicide bomber was killed and 28 others wounded.

s. On March 29, 2021 another suicide bombing occurred in front of the Cathedral Church.

In Indonesia acts of terrorism show a link between domestic and foreign groups. From the results of the disclosure of cases in Indonesia is an International terrorist network where its existence with all its activities can not be detected early so it is difficult to prevent and resist. The situation is similar to acts of terrorism in Pakistan, Palestine, Iraq and the Philippines. The Bali 1 and 2 bombings, the Australian Embassy bombings, the Filifina Embassy, the JW Merriot bomb and the Ritz Carlton showed a long barrage of acts of terrorism in Indonesia.

\subsection{Factors of the Occurrence of Criminal Acts of Terrorism in Indonesia}

Terrorism crimes are unique crimes, because the causative factors of this crime are very different from other crimes, such as money laundering, human trafficking, illegal drug trafficking and piracy of sea and illegal weapons trading. According to Bambang Pranowo, there are at least 5 factors that cause terrorism, namely:

\section{a) Etnicity, Nationalism/ Separatism}

This act of terror occurs in areas beset by inter-ethnic/tribal conflicts or in a nation that wants to self-destruct. Spreading terror is finally used as a way to achieve the goal or tool of struggle. The target is clear, namely ethnicity or other nations that are being fought.

\section{b) Poverty and Economic Disadvantage, Globalisation}


Poverty and inequality turned out to be social problems capable of terrorism. Poverty can be distinguished into 2 kinds (Supriyanto, 2020): natural poverty and structural poverty. Natural poverty is arguably "poor from its origin". While structural poverty is poverty created. This happened when the ruler instead issued a policy that even impoverished his people. The second type of poverty has a higher potential for the rise of terrorism.

\section{c) Non Democracy}

Non-democratic countries are also signaled as a place to thrive in terrorism. In a democratic country, all citizens have the opportunity to channel all their political views. The democratic climate makes the people the representation of the supreme power in the arrangement of the State. That is, the people feel involved in the management of the country. The same is certainly not the case in a non-democratic country. In addition to not providing opportunities for community participation, non-democratic rulers are very likely to also take repressive actions against their people. This curvature becomes a fertile culture for the growth of the seeds of terrorism.

\section{d) Violation of Human Dignity (Dehumanisation)}

Acts of terror will arise if there is discrimination between ethnic groups or groups in society. This happens when one group is treated unequally simply because of skin color, religion, or otherwise. Despised groups will look for ways for them to be heard, recognized, and treated equally with others. An atmosphere like this will again encourage the proliferation of terror.

\section{e) Radicalism of Religion}

This item seems familiar. Terror events that occur in Indonesia are widely connected to this cause. Religious radicalism is a unique cause because the underlying motives are sometimes unreal. It's different from poverty or easily observable discriminatory treatment. Religious radicalism is partly fostered by the worldview of its adherents.

A.C. Manullang in his book entitled "Uncovering the Taboos of Terror Intelligence, Motives and Regimes" states that the triggers of terrorism include religious, ideological and ethnic conflicts and widening the gap between the rich-poor. One of the triggers of terrorism is poverty and hunger. The fear of extreme hunger and poverty will easily trigger acts of violence and conflict, which are also fertile lava for the terrorism movement. Terrorism and radical movements also occur in developed and wealthy countries. Dissatisfaction or attitudes differ due to the continued social jealousy and growing between dominant and minority and marginalized groups in developed countries, as well as being marginalized continuously in the long run due to central government policies, especially since multilateral policies that make these marginalized groups can no longer tolerate the situation through formal and legal channels, motivating them more strongly to take alternative routes through violence.

\subsection{Solutions to Prevent and Combat Crime of Terrorism in Indonesia}


In order to prevent and overcome the threat of terrorism in the country, the Government has taken various ways, especially by taking actions in accordance with applicable legal procedures. Through the relevant authorities, the Government has approached through public figures, moderate religious leaders and those who tend to be radical to change radical thinking to moderate, namely by giving a real understanding of the term jihad that has been "misinterpreted".

Various efforts that the Government has made, especially the security measures in the disclosure of perpetrators of terrorism, received a mixed response among the public, especially Muslim groups sensitive to the issue of terrorism because it is associated with the Religion of Islam. They are strengthening differences in pro-and-contrast attitudes accordingly regardless of national interests, causing mutual suspicion among the public and distrust of the Government, especially the security apparatus in dealing with terrorism in Indonesia. In addition, ASEAN-level cooperation has been implemented.

The Government of Indonesia's careful attitude in preventing and tackling terrorists can be seen from the policies and anticipatory steps related to the Bali incident on October 12, 2002. In conducting the prevention and use of terrorism, the Government has established special institutions to deal with terrorism that has developed in the country in recent times, such institutions include:

\section{a) Intelligence}

The intelligence apparatus is coordinated by the State Intelligence Agency (Presidential Regulation No. 34 of 2010), which has conducted intelligence activities and coordination and has even established a Joint Analysist Terrorist (JAT) effort to uncover terrorist networks in Indonesia. Increased intelligence cooperation, both domestically and with foreign intelligence, through exchange of information and other assistance, continues to be improved. To narrow the movement space of perpetrators of terrorism activities, the Government will continue to encourage authorities to improve the control and supervision of the traffic of people and goods at airports, sea ports, and border areas, including traffic flows of funds, both domestic and interstate.

\section{b) TNI dan POLRI}

It has improved the performance of its anti-terror unit. The attempted arrest of those suspected of being a terrorism network in Indonesia in accordance with the provisions of the applicable Law still received a controversial reaction from some groups of the public and was colored by various comments through the mass media that led to the formation of opinions as if there was foreign pressure. In addition, control and supervision will be carried out on the commercial system and the use of explosives, chemicals, firearms and ammunition in the TNI, Police, and government agencies. In addition, the TNI, Police, and government agencies also continue to conduct in-depth assessments in collaboration with academics, community leaders, and religious leaders.

\section{c) International Cooperation}

Various cooperation efforts have been made, among others, with several countries such as Thailand, Singapore, Malaysia, Philippines, and Australia, even countries such as the United States, United Kingdom, Canada, France, and Japan. The issue of extradition between the 
Singapore and Indonesian governments has not been realized. Implications for Unity and Unity of the Nation. Public concern over the dangers of bomb terror still exists. This if not handled wisely will affect the wheels of the economy. On the other hand, the crackdown, arrest or examination by the authorities against who and the community organizations need to be careful not to cause negative sentiments among the community itself. The Government is considered discriminatory or appears biased on new issues nuanced SARA.

The improvement of the capabilities of various anti-terror and intelligence units in using primary sources and information networks is necessary in order to form a professional and integrated anti-terror apparatus from the TNI, Polri, and BIN. Furthermore, international cooperation needs to be improved because terrorism is a cross-border problem that has networks and channels that do not only exist in Indonesia.

The eradication of terrorism in Indonesia is not only a matter of law and law enforcement but also a social, cultural, economic problem that is closely related to the issue of national resilience so that its policies and preventive measures and eradication are aimed at maintaining the balance in the obligation to protect the sovereignty of the State, the human rights of victims and witnesses and the human rights of suspects or defendants.

Thus, efforts to prevent and counter terrorism can only be completed through cooperation and coordination between various stakeholders, both government agencies and the public. Therefore, the TNI and The National Police continue to conduct joint exercises given the importance of TNI-Polri cooperation for terrorism, so it is expected that the resolution of terrorism cases can be done better.

\section{Conclusion}

Terrorism is violence or threats of violence that are taken into account in such a way as to create an atmosphere of fear and danger with the intention of attracting national or international attention to an action or demand. Prevention and countering terrorism crimes requires a thorough cooperation by coordinating between government agencies, private or other civil elements because support and coordination in detecting and addressing various terrorist problems will be easily addressed. In addition, there is also a need for cooperation with anti-terrorism agencies located abroad which is certainly based on the legal framework, because with a solid legal basis will be the basis of national policy in the fight against terrorism.

\section{References}

[1] A.C Manullang, (2001). Menguak Tabu Intelijen Teror, Motif dan Rezim, Jakarta: Panta Rhei.

[2] Bambang Pranowo, (2011). Orang Jawa Jadi Teroris, Jakarta: Pustaka Alfabet.

[3] Anwar, N. S. (2019). Analisis Transaksi Digital Cryptocurrency Sebagai Investasi Global Dalam Perspektif Hukum Islam (Studi Kasus Dinar Dirham di Makassar).

[4] Gordon, J. M. (1998). Business Law: An Introduction. Business Law: An Introductionby TheBusinessProfessor.Com, 501(c), 428-431.

[5] Santiago, F. (2016). Bunga Rampai Catatan Hukum. Perpustakaan Nasional RI. Katalog Dalam Terbitan. 
[6] Supriyanto, Eko Eddya. 2020. Eksistensi Nilai-Nilai Pancasila Dalam Kebijakan Ekonomi Indonesia. 1st ed. Malang: Literasi Nusantara.

[7] Nababan, K. N. N. (2019). Tinjauan Legalitas Transaksi Bitcoin di Indonesia. JuristDiction, 2(5), 1745-1764. 